\title{
THE SENSITIVITY OF CAPITAL SERVICES INDEX ON CONSTRUCTION PRICE INDICES
}

\author{
Borut Kodric* $\quad$ Lea Bregar $^{\dagger}$
}

Keywords: Capital measurement, Index of capital services, Perpetual inventory method, Fixed asset price indices, Construction price indices

JEL: C43, O47

\begin{abstract}
Measuring capital is a challenging task due to numerous conceptual dilemmas and practical problems. In this paper, we focus on the production side of capital measurement where the reliable measurement of capital services is of vital importance for derived production measures, such as multifactor productivity. While there has been a lot of debate regarding the choice of expected rate of return, the choice of expected capital gain, and the treatment of taxes in the user cost estimation when estimating capital, not much attention has been paid to the issues of appropriate price indices of assets. The use of inappropriate asset price indices results in a biased estimate of capital services index and, consequently, influences the estimate of the impact of capital on economic growth. The purpose of this paper is to develop a framework of the impact of asset price indices
\end{abstract}

*asistant dr.Borut Kodric, Faculty of management, Cankarjeva 5, SI - 6000 Koper, Slovenija; e-mail: borut.kodric@fm-kp.si

†associate professor dr.Lea Bregar, Economic faculty, Kardeljeva plošcad 17, SI - 1000 Ljubljana, Slovenija; e-mail: lea.bregar@ef.uni-lj.si 
on capital services and to test the impact by the sensitivity analysis. The sensitivity analysis was carried out for the impact of construction prices on capital service index for the Slovenian manufacturing for the period 1995-2008.

\section{Introduction}

Measuring capital is a challenging task for researchers and national statistical offices (NSOs). Even within the comprehensive and consistent framework of the neoclassical theory of capital, there are still numerous problems regarding the methods of capital measurement.

In this paper, we focus on the measurement of capital services that is of vital importance for derived production measures, such as multifactor productivity. Conceptually, capital services are now well established thanks to the theoretical and methodological contributions of Jorgenson and Griliches (1967) and further contributions from Jorgenson (1995a, 1995b), Hulten (1990) and Diewert (2004). The issues regarding measuring the volume and price of capital services are mostly empirical, dealing with the choice of expected rate of return, the choice of expected capital gain, and the treatment of taxes in the user cost estimation (Baldwin et al., 2005, 127).

However, less attention has been paid to the issues of appropriate price indices of assets which are required in the process of assessment of capital services. The compilation of reliable price indices of fixed assets is particularly difficult due to heterogeneity of asset types and rapid technological improvement that makes the problems of separating value changes for capital goods into the price and volume components more complex than for other goods and services.

Compared to the statistics of consumption goods and production statistics, the statistics of capital goods is poorly developed, less reliable, and it exhibits some considerable gaps. This is also reflected on asset price indices the compilation of which is bound by available data, thus being far from recommended methodological standards (Eurostat, 2001). 
The review of empirical research on the measurement of capital services reveals that under such circumstances, researchers have to adopt some other 'secondbest' approaches, for instance, using input price indices to produce volume measures instead of output price measures, not paying particular attention to the bias introduced by inadequate price indices.

The purpose of this paper is to develop a framework of the impact of asset price indices on capital services and to test the impact by the sensitivity analysis. The sensitivity analysis was carried out for the impact of construction prices on the capital service index for the Slovenian manufacturing for the period 19952008. The decision to examine empirically the impact of asset price indices for construction assets was based on several reasons: first, the production of construction price indices together with a description of underlying methodology is a regular service of national statistical offices, thus giving us an opportunity to evaluate the deviations that are available from conceptually required data; second, the compilation of construction price indices exhibits all measurement problems and, consequently, possible sources of measurement errors, which are characteristic of asset price indices; third, constructions represent a considerable share of total assets in the majority of production processes.

\section{MEASURING CAPITAL}

When considering the contribution of a capital asset to the production process, it is generally agreed that the value of capital services produced by the asset is the appropriate measure and not the value of the asset itself. However, capital services that must be considered as a physical concept are not usually directly observable, rather approximated by the assumption that service flows are in proportion to the productive stock of a given type of asset.

The assessment of productive stock for each type of asset, most commonly done with the perpetual inventory method (PIM) described below, constitutes the first step towards measuring the quantity of capital services. In the second step it is necessary to construct an aggregate measure of the productive contribution of the different types of assets. 


\subsection{Construction of productive capital stock estimates by asset type}

The perpetual inventory method (PIM) enables the construction of productive stock for a particular asset on the basis of cumulated investment expenditure in past periods. In the first step it is necessary to express gross fixed capital formation (GFCF) in each period in constant prices. In the next step it is necessary to correct gross investment values for assets that have already been excluded from the production process because of wear and tear. Assuming that older assets are less productive in comparison with newer ones because of increased downtime, higher maintenance requirements or reduced speed or accuracy, investment from all surviving vintages is multiplied by the coefficient of their (relative) efficiency (Hulten, 1990, 121):

$$
K_{i, j, t}^{P}=\Phi_{i, 0} I_{i, j, t}+\Phi_{i, 1} I_{i, j, t-1}+\ldots+\Phi_{i, T} I_{i, j, t-T} ; \Phi_{i, 0}=1
$$

wherein:

$K^{P}{ }_{i, j, t}$ : is the productive stock of the fixed asset $i$ in industry $j$,

$I_{i, j, t}, I_{i, j, t-1}, \ldots, I_{i, j, t-T}$ : is the gross investment in the fixed asset $i$ in industry $j$ in each individual period expressed in constant prices and

$F_{i, 0}, F_{i, 1}, \ldots F_{i, T}$ : are the coefficients of relative efficiency of assets $i$ of a given age.

Weights $F_{i, t--v}$, reflect the relative efficiency of the assets $i$ of age $\mathrm{V}$ in comparison with a new asset, whereas the productive stock of capital $K^{P_{i, j, t}}$ can be interpreted as the number of units of a new asset necessary to achieve the same production capacity of past investment $\left(I_{i, j, t}, I_{i, j, t-1}, \ldots, I_{i, j, t-T}\right)$.

However, the capital estimation on the basis of PIM with (1) has to be considered as an approximation where its accuracy is mainly dependent on the accuracy of:

1. estimated efficiency coefficients $F_{t-v}$ (age-efficiency profile),

2. asset price indices used to deflate GFCF.

Efficiency coefficients are rarely observed directly and so indirect methods of inferring relative asset efficiency are necessary. The most common approach is 
to estimate the relative efficiency indirectly by assuming that the $\mathrm{F}^{\text {'s }}$ follow some pattern that depends on an observable useful life $T$. A plausible age-efficiency pattern for many asset types is a hyperbolic pattern (OECD, 2001a, 62) whereas the geometric form is widely used in theoretical expositions of capital theory because of its simplicity (Hulten, 1990, 125). For the same reason the geometric age-efficiency pattern is employed in this study.

The issues related to the estimation of asset price indices, being more complex and less explored, are discussed in detail in section 3.

\subsection{Aggregation across different asset types}

Since many different types of assets are used in modern production processes, an aggregate measure of different capital services must be constructed in the second step. Jorgenson (1963) and Jorgenson and Griliches (1967) were the first to develop an aggregate capital service measure that takes the heterogeneity of assets into account. They defined the flow of quantities of capital services individually for each type of asset, and then applied asset-specific user costs as weights to aggregate across services from the different types of assets.

Estimating user costs. - User costs are prices for capital services and, under competitive markets and equilibrium conditions, these prices reflect the marginal productivity of the different assets. Under the assumption of geometric depreciation pattern and in the absence of taxation, the user costs are expressed as:

$$
\mu_{i, j, t}=i_{j, t} p_{i, j, t-1}^{I}+\delta_{i} p_{i, j, t}^{I}-\left[p_{i, j, t}^{I}-p_{i, j, t-1}^{I}\right]
$$

wherein:

$\mu_{i, j, t}$ : is the price of capital services from asset type $i$ in industry $j$,

$p^{I}{ }_{i, j, t-1}$ : is the price for asset type $i$ in industry $j$ at the beginning of period $t$,

$p^{I}{ }_{i, j, t}$ : is the price for asset type $i$ in industry $j$ at the end of period $t$,

$i_{j, t}$ : is the nominal rate of return in industry $j$ and

$d_{i}$ : is the rate of depreciation for asset type $i$.

Equation (2), derived from the neoclassical theory of investment, shows that the user cost, reflecting the per-period cost of using the service of the asset, 
includes the cost for financing the purchase of the capital good, its economic depreciation and the capital gains-losses due to asset price changes. ${ }^{1}$

Despite the well developed theoretical paradigm, its empirical application is, however, not straightforward. If we ignore tax parameters in the user cost formulae, the most important issues in the user costs estimation can be considered the choice of expected rate of return and the choice of expected capital gains. According to the empirical evidence reported by Baldwin et al. (2005), Erumban (2008), Harper et al. (1989) and Iommi and Jona-Lasinio (2008), and theoretical advantages of the ex-post approach explicated by Baldwin et al. (2005), the model with internal rate of return (ex-post approach) and perfectly anticipated capital gain is employed in this study. The nominal rate of return in each industry is derived as a residual as follows:

$$
i_{j, t}=\frac{R_{j, t}+\sum_{i}\left[p_{i, j, t}^{I}-p_{i, j, t-1}^{I}\right] K_{i, j, t}^{P}-\sum_{i} p_{i, j, t}^{I} \delta_{i} K_{i, j, t}^{P}}{\sum_{i} p_{i, j, t-1}^{I} K_{i, j, t}^{P}}
$$

wherein:

$R_{, j, t}$ : is the capital compensation in industry $j$ in the period $t$,

Index number formula. - Once we have estimated the productive stock for different asset types and its user costs then we have to choose the specific index number formula by which the aggregation is done. The economic literature (Diewert, 1976, 1978; OECD, 2001a) recommends the use of superlative index numbers or index numbers with flexible weights that include the Fisher ideal index and the Törnqvist index.

Given observations on the productive capital stock for different types of assets, $K^{P}{ }_{i, j, t}$, and given a set of user cost weights, $\mu_{i, j, t}$, a Törnqvist index of capital services is given by the following expression:

Törnqvist quantity index of aggregate capital services $=\prod_{i}\left(\frac{K_{i, j, t}^{P}}{K_{i, j, t-1}^{P}}\right)^{\bar{v}_{i, j}}$

Where $\bar{v}_{i, j}=0,5\left(v_{i, j, t}+v_{i, j, t-1}\right)$ and $v_{i, j, t}=\frac{\mu_{i, j, t} K_{i, j, t}^{P}}{\sum_{i} \mu_{i, j, t} K_{i, j, t}^{P}}$.

Cost share weights allow accounting for heterogeneity in the marginal product of each asset type since they assign a relatively greater weight to the rates of change

\footnotetext{
${ }^{1}$ More comprehensive user cost definitions also include the net burden due to the tax structure for business income.
}

Borut Kodric, Lea Bregar - THE SENSITIVITY OF CAPITAL SERVICES INDEX ON CONSTRUCTION PRICE INDICES 
of the assets that have higher marginal product and allow accounting for the substitution among different asset types. This formulation is used in the capital service measurement in many studies on total factor productivity (Jorgenson, Gollop \& Fraumeni, 1987, Jorgenson, Ho \& Stiroh, 2005, EUKLEMS, 2007) as well as by several NSOs (US BLS, Australian Bureau of Statistics, for example).

\section{A framework for assessment of the impact of asset price indices on capital services estima- tion}

The price indices for a given asset type affect the aggregate index of capital services through estimates of the productive stock of the asset type as well as through relative user costs of the asset type in both a direct and indirect way. The relations between asset price indices and the index of capital services are rather complex. Figure 1 presents them schematically.

First, asset price indices have a direct impact on the estimates of GFCF in each period in constant prices of the chosen basic period (label 1 on Figure 1) reflected in the estimates of the productive stock of a given asset type (label 2 on Figure 1). Asset price indices also have a direct impact on the estimates of user costs of a given asset type since they include the capital gains/losses due to asset price changes (label 4a on Figure 1).

When the rate of return is estimated according to the ex-post approach, as a residual given the value of capital compensation from national accounts, the price indices for a given asset also have an indirect impact on user costs of all asset types through the altered internal rate of return (label $4 \mathrm{~b}$ on Figure 1), a consequence of altered relative capital gains-losses (label 3a on Figure 1) as well as altered estimates of the productive stock of a given asset type (label $3 \mathrm{~b}$ on Figure 1).

Thus, asset price indices do not affect capital services estimates only through the process of deflation of GFCF, as frequently presented, but also indirectly, through the impact on user costs being a factor of weighting scheme of calcula- 
Economic Research - Ekonomska Istrazivanja Vol. 25(3)

tion index of capital services at aggregate level.

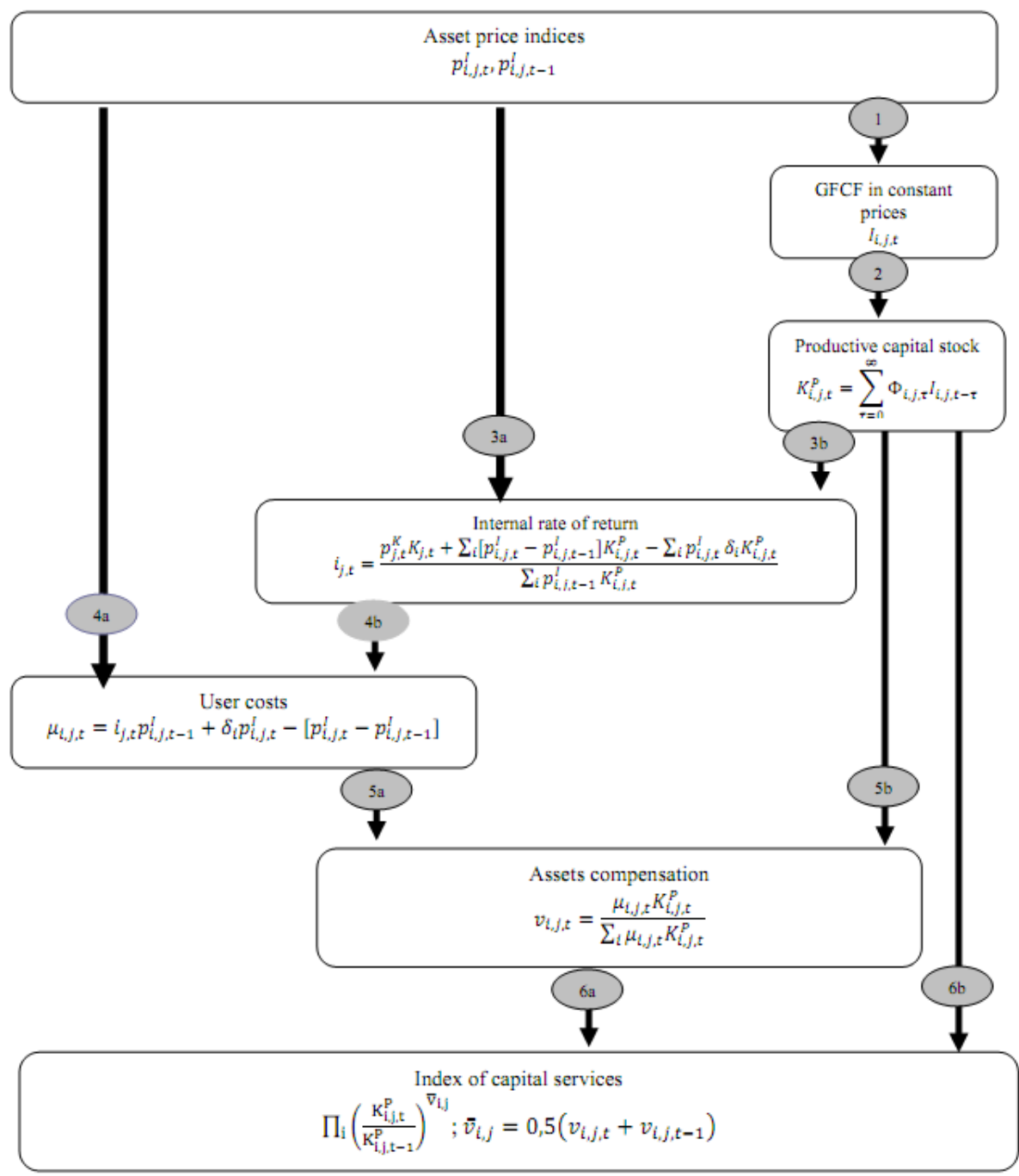

FIGURE 1- The impact of asset price indices on the index of capital services Source: Author calculation

Taking into consideration the role asset price indices have in the process of

Borut Kodric, Lea Bregar - THE SENSITIVITY OF CAPITAL SERVICES INDEX ON CONSTRUCTION PRICE INDICES 
capital services estimation, they have to fulfill the following criteria in order to provide reliable deflated values of GFCF and user cost estimates (Eurostat, 2001, 43):

1. the price index must include coverage of exactly that (group of) prod$\operatorname{uct}(\mathrm{s})$;

2. when compiling price index, changes in quality of the product(s) must be properly taken into account;

3. the price index is valued in purchasers' prices including non-deductible VAT; and

4. the concepts underlying the index correspond to those of national accounts.

However, fulfillment of these criteria can be hampered by several problems. One of the most difficult problems in price and volume measurement is the problem of quality changes ${ }^{2}$ that are more severe for capital goods than for other goods and services. Many capital goods are unique or "one off', representing a discontinuity in the calculation of price indices. This is particularly the case with most buildings, construction work and large equipment goods such as ships, oil rigs, aircraft, special purpose machinery and tailored business services.

Eurostat's handbook on price and volume measures in national accounts (Eurostat, 2001, 23-24) suggests two approaches for the calculation of price indices for unique products (services) - "model pricing" and "specification pricing". However, both of them are resource-intensive methods and not all NSOS can afford such practices.

\footnotetext{
${ }^{2}$ In principle, whenever a characteristic of a product changes, it is to be considered a different quality of the product. These changes in characteristics are to be recorded as changes in volume and not as changes in price (cf. ESA95, par. 10.16).
}

Borut Kodric, Lea Bregar - THE SENSITIVITY OF CAPITAL SERVICES INDEX ON CONSTRUCTION PRICE INDICES 


\section{Construction price indices as deflators of GFCF}

As has already been explained, the compilation of construction price indices deserves particular attention. One of the major problems in the process of compilation of construction price indices is the problem of heterogeneity which is caused by the diversity of construction activity. The term construction covers a wide variety of activities, such as the construction of dwellings, non-residential buildings, and civil engineering works, as well as major improvements of existing structures and regular repairs and maintenance.

The methods used to compile construction price indices vary significantly between countries. Individual countries also use a variety of methods and data sources for the different construction price indices they produce. However, the majority of countries use input price indices for deflation purposes (Eurostat, 2001, 75), since they are the simplest and least expensive indices to construct. Input price indices measure changes in the price of direct inputs in the construction process. This generally entails the compilation of a weighted index (fixed weights) of the costs of wages and materials for the representative object.

When assessing the relevance of input price indices used in the process of capital services estimation, we must take into consideration the basic criteria already discussed in section 3 - consistency with National Accounts concepts, use of the appropriate purchasers' price valuation, providing the full coverage of the activities under the classification heading and treatment of quality changes as volume changes. Of course, the price indices should be compiled from actual rather than list prices and should ensure that all measures are appropriate to the time period (Eurostat, 2001, 43).

The coverage of construction activities and the appropriate level of product detail is the biggest advantage of input price indices, since they are usually available for housing and estate buildings, civil engineering works, buildings for industrial use and building renovations. However, due to the methodological issues presented below, the use of input price indices is classified as an inappropriate way to produce volume measures (Eurostat, 2001).

First, the input price indices do not reflect the whole range of influences that im- 
pact construction purchaser's prices - which are changes in productivity, profit, and trade margins of the construction contractor as well as costs incurred in the transfer of ownership and any taxes payable on the transfer.

The next important issue is the treatment of quality changes. The standard method of compilation of an input price index starts with the selection of a representative construction and evaluation of the quantities of each constituent element. The quantities of elements representing weights in the process of input price index calculation remain fixed. Consequently, an input price index measures changes of costs at constant technology and constant input mix that are associated with the implementation of a fixed amount of construction work (Eurostat, 2006, 76). Hence, the quality changes are ignored by definition, a big disadvantage of input price indices since structures are very heterogeneous.

According to the role asset price indices have in the process of capital services estimation, discussed in section 3 , it can be easily understood that the use of inappropriate or biased construction price indices, like the direct use of input price indices, results in a biased estimate of capital services index, the magnitude of the bias being proportional to the contribution of constructions to the aggregated capital services. The empirical evidence on how the biased estimates of construction price indices affect the estimate of the aggregate index of capital services is provided in the following section.

\section{Analysis of Impact of Construction Price In- dices on Capital Services Index}

\subsection{Data and methodology}

The assessment of the impact of construction price indices on the aggregate index of capital services has been made for Slovenian manufacturing industries during the period 1995-2008. We estimated both the productive capital stock and the user cost of capital for ten asset types that comprises GFCF: residential structures, non-residential buildings and other structures, transport 
equipment, computing equipment, communications equipment, other machinery and equipment, other tangible assets (cultivated assets), major improvements to tangible non-produced assets and costs associated with the transfer of ownership of non-produced assets, software and other intangible fixed assets. Nonresidential buildings and other structures (NRBOS) mostly consist of industrial and commercial buildings, since civil engineering objects are usually not owned by production units classified in manufacturing industries.

At the lowest level of aggregation, we estimated productive capital stock and the user cost of capital for 22 divisions of manufacturing industries (2-digit numerical code). ${ }^{3}$ The industries are classified according to Slovenian standard classification of activities (SKD 2002 - national version of NACE Rev. 1).

Finally, we estimated the aggregate capital services index for manufacturing industries with the use of the Törnqvist index number formula, wherein the weights represented relative proportions of aggregate capital compensation by divisions.

Data on gross capital stock by asset types for the reference year 1999, collected with the census of fixed assets ${ }^{4}$, were used as a key data source for an initial benchmark estimate of productive capital, needed to implement the PIM, presented in section 2 with (1). Data on GFCF for the period 1995-2008 were taken from National Accounts. ${ }^{5}$

It has to be noted, however, that the deflators used by SORS to produce official National Account Data on GFCF in constructions are compiled as input

\footnotetext{
${ }^{3}$ This level of detail (2-digit numerical code), also known as the A60 breakdown, is often used in European statistics.

${ }^{4}$ The census, carried out in the years 2000-2001 for the reference year 1999, was carried out as part of the subproject entitled "Methodology, Organisation and Implementation of Fixed Capital Statistics" within the STATCOP 98 programme financed by EU. Data collected with this project should present a basis to establish the PIM method for the estimation of gross capital stock and capital stock consumption in accordance with ESA 95. The data used in this study must be considered as preliminary.

${ }^{5}$ The only exception were deflators for computing equipment and application software, that have been, according to harmonization procedure introduced by Schreyer (2002), estimated on the basis of US price indices for computer and electronic products and application software published by BEA
}

Borut Kodric, Lea Bregar - THE SENSITIVITY OF CAPITAL SERVICES INDEX ON CONSTRUCTION PRICE INDICES 
price indices with Laspeyres fixed weights, similar to the majority of countries, although this approach is considered an unacceptable way to produce volume measures (Eurostat, 2001, 75). As already pointed out in the section 4, input price indices are likely to be biased indicators of price changes of completed construction work, and as such affect several components which enter into the compilation of index of capital services (see Figure 1), proportionally to their contribution to aggregate capital services.

Considering the poor empirical evidence it was almost impossible to make a reliable estimate of the magnitude of this bias. Hence, we decided to conduct a sensitivity analysis with several different hypothetical scenarios which we designed according to the findings of the appraisal of input price indices as deflators presented in section 4 and findings reported by some studies considering various sources of bias in price indices.

\subsection{Sensitivity analysis design}

Our point of departure was the assumption that the shares of costs of the transfer of ownership, taxes payable on the transfer and trade margins in purchasers' prices, have not been changed in the given period. Consequently, neglected changes in productivity, profit and quality represented main sources of bias.

Due to the lack of other relevant data sources, the correction for changes in productivity in construction activity was the only one we could actually perform. We took estimates of total factor productivity (TFP) in construction activity for the period 1995-2006, published in the EUKLEMS database, as a benchmark. Since the data was available only for the period 1995-2006, we assumed no change in TFP occurred in 2007 and 2008.

When trying to define relevant assumptions regarding the sign and the magnitude of bias caused by neglected profits and quality changes, we considered empirical evidence presented by Feenstra (1995), Gordon (1990), Hobijn (2001, 2002), Pieper (1990) and Triplett (1972, 1988, 2002).

Since profits are pro-cyclical (Pieper, 1990) and the output growth was positive through the whole studied period, we assumed that input price indices understated the growth of construction prices. However, being unable to estimate 
the size, we conservatively assumed input price indices underestimated the actual growth of construction prices by $1.00 \%$ annually, due to the bias caused by neglected profits, all other things remaining equal.

Even more problems were related to the assumption regarding the sign of the quality bias. It is commonly believed that price index methods tend to overestimate actual inflation in markets where there is a rapid turnover of goods due to technological progress. The support for such reasoning can be found in the evidence reported by the Boskin (1996) commission with respect to the U.S. Consumer Price Index, while Gordon (1990) used hedonic price indexes to correct for this bias in equipment price indexes (Hobijn, 2002). In contrast, Hobijn (2001, 2002), as well as Triplett $(1972,1988,2002)$ and Feenstra (1995) have each made the point that quality adjustments in price index methods might actually lead to an understatement of inflation. ${ }^{6}$ Hence, the quality bias in price indexes is not by definition upward.

Considering the results reported by Gordon (1990), that the official national income and product accounts' (NIPA) deflator for producers' durable equipment for the period 1947-83 overestimated the price rise for exactly the same commodities by $2.96 \%$ annually, we assumed the value of $3.00 \%$ as the upper margin of the possible positive quality bias. ${ }^{7}$ In addition, we defined an alternative scenario assuming the negative quality bias. In this case we assumed the input price indices underestimated the actual growth of construction prices by $0.50 \%$ annually due to quality bias, all other things being equal, considering the findings reported by Hobijn (2002).

According to the assumptions presented above, we defined the following scenarios for the sensitivity analysis:

\footnotetext{
${ }^{6}$ One reason that production costs per quality unit might be increasing in the number of quality units is that the best models are the newest and learning by doing reduces production costs over time at a higher rate than quality per model grows (Hobijn, 2002, 23).

${ }^{7}$ It has to be noted that Gordon's estimate referring to the period 1947-83 cannot be directly referred to regarding the period of our analysis, 1995-2008. However, from the methodological point of view limitations he identified for NIPA deflator for producers' durable equipment are much the same as in the case of official input price indices used by SORS for deflating GFCF in constructions.
}

Borut Kodric, Lea Bregar - THE SENSITIVITY OF CAPITAL SERVICES INDEX ON CONSTRUCTION PRICE INDICES 
1. Scenario 1: adjustment of official input price indices for changes in productivity only;

2. Scenario 2: adjustment for changes in productivity and profit rate;

3. Scenario 3: adjustment for changes in productivity, profit rate and downward adjustment due to assumed positive quality bias and

4. Scenario 4: adjustment for changes in productivity, profit rate and upward adjustment due to assumed negative quality bias.

Table 1 provides an overview of the adjustments made to input price indices according to each of the assumed scenarios.

TABLE 1 - Overview of scenarios for the sensitivity analysis

\begin{tabular}{lccc}
\hline \hline Scenario & $\begin{array}{l}\text { Adjustment for changes in } \\
\text { productivity }\end{array}$ & $\begin{array}{l}\text { Adjustment for changes } \\
\text { in profit rate }\end{array}$ & $\begin{array}{l}\text { Adjustment for } \\
\text { quality changes }\end{array}$ \\
\hline Scenario 1 & $\uparrow / \uparrow *$ & - & - \\
Scenario 2 & $\uparrow / \uparrow *$ & $\uparrow(1.00 \%)$ & - \\
Scenario 3 & $\uparrow / \uparrow *$ & $\uparrow(1.00 \%)$ & $\downarrow(3.00 \%)$ \\
Scenario 4 & $\uparrow / \uparrow *$ & $\uparrow(1.00 \%)$ & $\uparrow(0.50 \%)$ \\
\hline \hline
\end{tabular}

Source: Author calculation

*: According to estimated TFP

\subsection{Results}

Each of the scenarios was evaluated in accordance with the framework presented in section 3 where special attention was paid to effects that adjustments had on:

1. growth of prices of NRBOS;

2. productive stock of NRBOS estimates and

Borut Kodric, Lea Bregar - THE SENSITIVITY OF CAPITAL SERVICES 
3. aggregate index of capital services.

Growth of prices. - The prices of $\mathrm{NRBOS}^{8}$ in manufacturing industries in Slovenia have risen on average by $7.65 \%$ annually or by $160.70 \%$ over the given period (label 'Official' on Figure 2).

The result of correction for productivity change (label 'Scenario 1' on Figure 2 ) is most evident in the period 1996-2000, when the growth of productivity in construction activity was positive; hence, input price indices overestimated the actual inflation. However, we consider this correction as rather conservative, since TFP estimates published in the EUKLEMS database are based on output data in the construction industry being deflated with input price indices, thus very probably underestimating the actual productivity growth.

Additional correction for profits (label 'Scenario 2' on Figure 2) resulted in faster growth of NRBOS prices from 2000 on, in comparison to official estimates. The average growth of NRBOS prices, according to scenario 2, would be $8.73 \%$ annually.

Assuming the positive quality bias, in addition to adjusting input prices for changes in productivity and profit rate (label 'Scenario 3' on Figure 2), resulted in remarkable downward adjustment of input prices. The prices of NRBOS would rise, according to scenario 3, by only $5.46 \%$ annually or by $99.69 \%$ over the given period. In contrast, upward adjustment for quality change (label 'Scenario 4' on Figure 2) resulted in much higher growth of prices $-9.27 \%$ annually or by $216.58 \%$ overall.

FIGURE 2 - Deflators of items of non-residential buildings and other structures within GFCF, 1995-2008, 1995=100

Considering that Scenario 3 and Scenario 4 represent a lower and upper margin of the estimated growth of NRBOS prices, we concentrated on just these two scenarios in the following.

\footnotetext{
${ }^{8}$ We focused on the impact of price indices of non-residential buildings and other structures only, since the contribution of residential structures in the aggregate capital services growth in manufacturing industries in the given period was negligible. However, the contribution of residential buildings is taken into account when calculating the aggregate index of capital services.
}

Borut Kodric, Lea Bregar - THE SENSITIVITY OF CAPITAL SERVICES INDEX ON CONSTRUCTION PRICE INDICES 
Productive capital stock. - Figure 3 shows benchmark estimates of productive stock of NRBOS in Slovenian manufacturing industries, compiled on a basis of official deflators, as well as estimates compiled according to Scenario 3 and Scenario 4.

Scenario 3, characterized by the slowest growth of NRBOS prices, led to the highest estimates of productive stock of NRBOS, which are on the average $23.95 \%$ higher than benchmark estimates in the whole studied period. The positive difference is to be expected since asset price indices have a direct impact on the estimates of GFCF in each period in constant prices, as is reflected in the estimates of the productive stock of a given asset type (Figure 1). An upward bias of an asset price index results in a downward bias of GFCF in constant prices of a given asset type and thus in an underestimated productive stock of a given asset type.

According to Scenario 4, NRBOS prices showed somewhat slower growth in the years 1996-1999, comparing to official estimates, resulting in higher estimates of productive stock of NRBOS in these early years. However, the gap is being closed due to accelerated growth of NRBOS prices from 2000 on.

FIGURE 3 - Productive stock of non-residential buildings and other structures in Slovenian manufacturing industries, 1995-2008, reference year 1995

Capital services. - Figure 4 shows estimates of the Törnqvist aggregate index of capital services based on official NRBOS prices, as well as on two alternative scenarios. As it has been already explained in Section 3, differences between various aggregate capital services estimates are the result of the direct impact of deflators of GFCF in constructions on productive capital stock estimates as well as direct and indirect effects on user costs of capital. Differences in aggregate capital services are almost negligible, especially between estimates based on official deflators and estimates based on Scenario 3, despite a quite different growth path of NRBOS prices considered in both cases (see Figure 2).

The volume index of aggregate capital services at the aggregate level, based on official deflators, shows an increase of $41.92 \%$ over the full period or $2.73 \%$ annually. Considering Scenario 3 - the increase would be $41.68 \%$ over the full period ( $2.72 \%$ annually), whereas the overall increase would be only $38.45 \%$ 
( $2.53 \%$ annually) when considering Scenario 4 .

The magnitude of differences between capital services estimates based on alternative scenarios varies slightly in some divisions when looking at a disaggregate level depending on the contribution of NRBOS to overall capital services in the selected division. For example, in the division Manufacture of coke and refined petroleum products (DF), the difference between the capital services estimate based on official deflators and the estimate based on Scenario 4 is almost negligible, whereas the largest difference between the capital services estimate based on official deflators and the estimate based on Scenario 4, approximately $3.29 \%$, can be seen in the division Manufacture of chemicals and chemical products (DG).

FIGURE 4 - Aggregate capital service in Slovenian manufacturing industries, 1995-2008, 1995=100

Rather small impact of construction price indices at aggregate level of capital services is expected. It has to be taken into account that the bias in price indices for selected asset type is translated into biased capital services estimate depending on the contribution of selected asset type to aggregate capital services - the larger the contribution of the selected asset type, the more the capital services estimate is sensitive to the bias in the selected asset price indices.

Despite very similar growth paths of aggregate capital services, it must not be overlooked substantially greater differences in the contribution from NRBOS services to overall growth of capital services, considering each of the scenarios. When using official deflators NRBOS account for about $35.02 \%$ of the overall growth of capital services over the full period, whereas the contribution would be only $27.28 \%$ considering scenario 4 , with the highest growth of NRBOS prices.

\section{Conclusions}

The measurement of capital is one of the most difficult and contentious areas of official statistics. The methodological issues related to the measurement of capital are much more complex in comparison with other traditional topics of official statistics like the measurement of output or labour. 
In this paper, we focused on the measurement of capital services and the frequently overlooked role of asset price indices in this process, developing a framework to assess the impact of asset price indices on the capital services estimation. The presented framework could be useful whenever considering the role of any asset type and its deflator in the capital services estimation. This is often the issue due to the important role of asset price indices in the process of capital services estimation. We tested the impact by the sensitivity analysis for the impact of construction prices on the capital service index for Slovenian manufacturing for the period 1995-2008.

The results show that input price indices are likely to be the biased indicators of the price changes of completed construction work, and as such affect derived estimates. In this paper, we illustrated, based on some hypothetical scenarios, that adjusting for some elements which are not respected in the current compilation of construction price indices, such as productivity, profit rate and quality changes, could have a noticeable effect on the growth path of construction price indices and, consequently, on productive stock and user costs estimates as well. In the case of the Slovenian manufacturing industries, the differences reflected in the aggregate capital services estimates in the sample period are very small or even negligible in some cases. The largest difference, identified between the capital services estimates for the period 1995-2008, based on the official construction deflators and the deflators corrected for productivity, the profit rate and the assumed negative quality bias is 3.46 index points.

However, when interpreting these results at the aggregate level, several factors have to be taken into account. First, the sensitivity of capital services estimates to the bias incorporated in asset price indices depends on the contribution of selected asset type, in our case constructions, to aggregate capital services. In some manufacturing industries where the contribution of constructions is larger than in manufacturing as a whole, the capital services estimates and, consequently, the total factor productivity estimates, which are primarily used for the index of capital services, could be more sensitive to the bias in construction price indices.

Second, despite negligible differences between the capital services estimates 
produced by alternative hypothetical scenarios, there is a noticeable difference between estimated contributions of constructions to aggregate capital services growth, considering alternative scenarios. This finding has important implications for the identification of the sources of economic growth.

The case study of construction price indices for the manufacturing in Slovenia in the period 1995- 2008 based on the general framework for assessment of the impact of asset price indices on the capital services estimation revealed that the validity of various empirical economic studies related to capital services depends also on the quality of data input where asset price indices could have a considerable effect on the empirical results, particularly when studying the capital stock and contribution of assets to economic growth. The comprehensive evaluation of the asset price indices on the aggregate index of capital services would require further research efforts in the assessment of price indices of other assets (e.g., machinery, information and communication technology, etc). The importance of appropriate asset price indices for the economic analysis (not only for an appropriate measurement of price movements but also for the quality measurement of capital services) should also encourage official statistics to pay more professional attention to this field of economic statistics. 


\section{References}

Baldwin J.R, Gu W., Harchaoui T., Tarkhani F. 2005. Multifactor Productivity in Canada: An Evaluation of Alternative Methods of Estimating Capital Services, Yearbook on Productivity 2005, Statistics Sweden: 127-178.

Boskin, Michael J., Ellen R. Dulberger, Robert J. Gordon, Zvi Grilliches, Dale Jorgenson. 1996. Toward A More Accurate Measure of the Cost of Living, Final Report of the Advisory Commission to Study The Consumer Price Index.

Diewert W.E. 1976. Exact and Superlative Index Numbers, Journal of Econometrics 4: 115-45.

Diewert W.E. 1978. Superlative Index Numbers and Consistency in Aggregation, Econometrica 46: 883-900.

Diewert W.E. 2004. Issues in the Measurement of Capital Services, Depreciation, Asset Price Changes and Interest Rate. Department of Economics, University of British Columbia, Discussion Paper No. 04-11.

Erumban, A.A. 2008. Capital Aggregation and Growth Accounting: A Sensitivity Analysis. EUKLEMS Working Paper No.25, 31 p.

EUKLEMS. 2007. EU KLEMS Growth and Productivity Accounts, Version 1.0 .

Eurostat. 2001. Handbook on Price and Volume Measures in National Accounts. Luxembourg: Office for Official Publications of the European Communities.

Eurostat. 2006. Methodology of short-term business statistics - Interpretations and guidelines. Luxembourg: Office for Official Publications of the European Communities.

Feenstra, R.C. 1995. Exact Hedonic Price Indexes, Review of Economics and Statistics 77: 643-653.

Gordon, R. 1990. The Measurement of Durable Goods Prices. NBER monograph. The University of Chicago Press. 723 p.

Borut Kodric, Lea Bregar - THE SENSITIVITY OF CAPITAL SERVICES

INDEX ON CONSTRUCTION PRICE INDICES 
Harper, M.J., Berndt, E.R. \& Wood D.O. 1989. Rates of Return and Capital Aggregation Using Alternative Rental Prices, in Dale W. Jorgenson and Ralph Landau (eds.), Technology and Capital Formation, Cambridge, MA, MIT Press: 331-372.

Hobijn, B. 2001. Is Equipment Price Deflation A Statistical Artifact?, Staff Report 139, Federal Reserve Bank of New York.

Hobijn, B. 2002. On Both Sides of the Quality Bias in Price Indexes, Federal Reserve Bank of New York.

Hulten, C.R. 1990. The Measurement of Capital in Ernst R.Berndt and Jack Triplett (eds.) Fifty Years of Economic Measurement, NBER Studies in Income and Wealth, Vol. 54. The University of Chicago Press: 119-158.

Iommi, M., Jona-Lasinio, C. 2008. New Technologies and the Growth of Capital Services: a Sensitivity Analysis for the Italian Economy Over 1980-2003 in Swiss Federal Statistical Office (FSO) and OECD (eds), Productivity Measurement and Analysis: Proceedings from OECD Workshops. Swiss Federal Statistical Office (FSO), Neuchatel.

Jorgenson, D.W. 1963. Capital Theory and Investment Behaviour. American Economic Review 53: 247-259.

Jorgenson, D.W. 1995a. Postwar U.S. Economic Growth. Cambridge, The MIT Press.

Jorgenson, D.W. 1995b. International Comparisons of Economic Growth. Cambridge, The MIT Press.

Jorgenson, D.W., Gollop, F.M., Fraumeni B.M. 1987. Productivity and U.S. Economic Growth, Harvard University Press, Cambridge, Massachussetts. Jorgenson, D.W., Ho, M.S. \& Stiroh, K.J. 2005. Growth of U.S. Industries and Investments in Information Technology and Higher Education, NBER Chapters, in: Measuring Capital in the New Economy, National Bureau of Economic Research, Inc.: 403-478.

Jorgenson, D.W., Griliches, Z. 1967. The Explanation of Productivity Change, Review of Economic Studies 34: 249-83.

OECD. 2001a. Measuring Productivity OECD Manual: Measurement of Aggregate and Industry-level Productivity Growth, OECD, 154 p. 
Pieper, P. 1990. The Measurement of Construction Prices: Retrospect and Prospect in Berndt, E. and Triplet, J. Fifty Years of Economic Measurement: The Jubilee of the Conference on Research in Income and Wealth. The University of Chicago Press. Chicago, Illinois.

Schreyer, P. 2002. Computer Price Indices and International Growth and Productivity Comparisons, Review of Income and Wealth, Vol. 48, No.1.

Triplett, J.E. 1972. Quality Bias in Price Indexes and New Methods of Quality Measurement., in Price Indexes and Quality Change: Studies in New Methods of Measurement, Zvi Grilliches (ed.), Cambridge, MA: Harvard University Press. Triplett, J.E. 1988. Price index research and its influence on data: A historical review. Paper presented to the 50th anniversary conference of the Conference on Research on Income and Wealth, Washington, DC.

Triplett, J.E. 2002. Quality Adjustments in Conventional Price Index Methodologies, Handbook on Quality Adjustment of Price Indexes For Information and Communication Technology Products, OECD: Paris. 


\title{
OSJETLJIVOST INDEKSA KAPITALNIH USLUGA NA INDEKSE GRAĐEVINSKIH CIJENA
}

\author{
Sažetak
}

Mjerenje je kapitala još uvijek izazovan zadatak zbog brojnih konceptualnih dilema i praktičnih problema. U ovom se članku fokusiramo na produkcijsku stranu mjerenja kapitala gdje je pouzdano mjerenje usluga kapitala ključne važnosti za izvedene mjere proizvodnje kao što je višefaktorska produktivnost. Dok je bilo puno rasprava koje su se odnosile na problematiku očekivanog stupnja naknade, problematiku očekivanog dobitka od kapitala i tretiranje poreza u procjenjivanju troškova korisnika, mnogo manje pažnje bilo je posvećene pitanjima odgovarajućih cjenovnih indeksa sredstava koji su potrebni u procesu procjenjivanja usluga kapitala. Primjena neodgovarajucih indeksa cijena sredstava dovodi do pristrane procjene indeksa usluga kapitala i prema tome utječe na procjenu učinka kapitala na gospodarsku rast. Svrha je ovog članka postaviti generalni okvir utjecaja indeksa cijena sredstava na usluge kapitala i testirati taj utjecaj pomoću analize osjetljivosti. Analiza je osjetljivosti bila izradena za utjecaj indeksa cijena gradevinarstva na usluge kapitala za preradivačku industriju u Sloveniji za razdoblje 1995-2008.

Ključne riječi: mjerenje kapitala, indeks usluga kapitala, metoda trajne inventure, indeksi cijena osnovnih sredstava, indeksi cijena građevinarstva, indeksi cijena proizvodnih čimbenika

Borut Kodric, Lea Bregar - THE SENSITIVITY OF CAPITAL SERVICES 